Eur. J. Clin. Chem. Clin. Biochem.

Vol. 32, 1994, pp. $821-825$

(c) 1994 Walter de Gruyter \& Co. Berlin · New York

\title{
Oxalic Acid in Saliva, Teeth and Tooth Tartar
}

\author{
By R. Wahl and E. Kallee
}

Medizinische Klinik und Poliklinik, Abt. IV, Eberhard-Karls-Universität Tïbingen, Tübingen, Germany

(Received June 6/August 31, 1994)

Summary: Oxalic acid was determined in human saliva, teeth, tartar, and in animal teeth. Saliva from dentally healthy male subjects contained $0.10 \pm 0.09 \mathrm{mmol} / \mathrm{l}(\mathrm{n}=41)$ and those of dentally healthy female subjects $0.18 \pm 0.17 \mathrm{mmol} / \mathrm{l}(\mathrm{n}=40)$. Oxalic acid in tartar from 16 patients was $3.3 \pm 1.2 \mathrm{mmol} / \mathrm{kg}$ tartar. In human teeth, oxalic acid was $1.0 \pm 0.3 \mathrm{mmol} / \mathrm{kg}$ in milk teeth $(\mathrm{n}=12)$ and $0.9 \pm 0.6 \mathrm{mmol} / \mathrm{kg}$ in permanent teeth $(\mathrm{n}=60)$. Human teeth were sorted into age groups and into molars, incisors and premolars. In animal teeth, oxalic acid content varied widely. The formed calcium oxalate is proposed to be a 'physiological' protective mechanism for teeth.

\section{Introduction}

Organic acids play an important role in the development of caries (1). Oxalic acid, the simplest dicarbonic acid, plays a special role in this process. It is a strong acid with two dissociation constants $\left(\mathrm{pK}_{1}=1.23\right.$ and $\mathrm{pK}_{2}$ $=3.83$ ). For humans, oxalic acid is a non-essential nutrient (2). On the other hand, the body itself produces oxalic acid, in particular by the decomposition and conversion of glycine (3) and ascorbic acid $(4,5)$.

According to Gortner et al. (6), dietary oxalic acid is deposited as calcium oxalate crystals on tooth enamel in rats. Thirty years later, oxalic acid was found to be associated with dentin by Pashley et al. (7). They treated the dental smear layer resulting from grinding with soluble oxalates and determined that calcium oxalate developed within seconds. The nearly insoluble calcium oxalate was able to strengthen chemically the physical blockage of the dentinal canals resulting from the smear layer.

Oxalic acid is a physiological component of the blood. Its salts, in particular calcium oxalate, can occur in various human tissues, including in salivary stones (8). It can thus be assumed that the teeth are continuously awash in oxalic acid through saliva. It was the goal of this study to investigate the oxalate content not only in saliva and in tooth tartar but also in teeth, because in bone, a similar material, we have also discovered oxalate.

\section{Methods}

Materials

Saliva

The saliva samples examined consisted of mixed saliva gathered by spitting in the late afternoon from persons with and without caries, as well as from smokers. The saliva samples $(5 \mathrm{ml})$ were immediately deep-frozen and lyophilised 12 hours until dry, then stored tightly closed at $-20^{\circ} \mathrm{C}$ up to one week for the measurement of the oxalic acid content.

The dry substance was weighed, suspended in $2 \mathrm{ml}$ of an aqueous solution containing EDTA $(8.86 \mathrm{~g} / \mathrm{l})$ and adjusted with $\mathrm{HCl}$ to a $\mathrm{pH}$ between 1.5 and 3. The sample was heated for approximately 40 minutes to $60^{\circ} \mathrm{C}$ in a water bath and then centrifuged. The supernatant was measured for its oxalate content.

\section{Teeth}

Freshly extracted human teeth, sorted as well as possible by dentition, age and sex were cleaned of remaining blood under cold running water, dried and freed from any remaining bone, periodontal membrane, and tartar with a scalpel. Finally the samples were preserved in liquid nitrogen. For the determination of oxalate the deepfrozen teeth were crushed with a hammer, and any remaining fillings and the pulp removed with a forceps. In a bronze-mortar the tooth fragments were ground to a powder in liquid nitrogen and then weighed. For the determination of oxalic acid the tooth pow- 
der and the tartar were dissolved in $8.5 \mathrm{~mol} / \mathrm{H} \mathrm{HCl}$ (approx. $2 \mathrm{~g}$ dental material $/ 10 \mathrm{ml} \mathrm{HCl}$ ) and heated approx. 40 minutes to $60^{\circ} \mathrm{C}$ in a water bath to accelerate the solubilization and to destroy enzymes which could perhaps interfere with the enzymatic oxalate determination. Oxalate dissolves in this process quantitatively, but does not decompose at this temperature. The resulting solution had a $\mathrm{pH}$ value of $<3$, which meets the requirements of the test equipment used. The solution was finally filtered to remove insoluble components and then immediately measured for oxalic acid. The oxalic acid content in solubilized teeth had dropped significantly even after approximately one week, and after approx. 3 weeks, no oxalate was measurable in the solution. The reason for this is still not clear.

During the dissolution of the individual teeth in acid, the sample solution took on various colourations, ranging from light yellow to dark. An influence of the solubilized teeth's own colour on the absorbance measurement in the enzymatic measurement of oxalic acid could be ruled out. The solution with the solubilized teeth was diluted by factor 30 for the oxalic acid determination. The darkest sample solution showed in dilution an absorbance of only -0.04 compared to a blank.

A series of animal teeth was prepared in the same manner as the human teeth.

\section{Tartar : :}

The examined tartar came from patients with very carious teeth, and was stored and processed in the same manner as the teeth.

\section{Determination of the oxalic acid content}

A test set from Sigma Diagnostics (Deisenhofen, Germany) was used for the actual oxalate determination. As this test equipment is designed for the determination of oxalic acid in urine, the samples had to be adapted accordingly. The determination method used is based on the oxidation of oxalate by oxalate-oxidase ${ }^{\mathrm{l}}$ ), and leads to the formation of carbon dioxide and hydrogen peroxide. The resulting $\mathrm{H}_{2} \mathrm{O}_{2}$ was measured by the formation of a blue indamine dye. The maximum absorbance of this dye was determined with a spectral photometer (Response ${ }^{\circledR}$ spectral photometer, Gilford, Giessen, Germany) at $592 \mathrm{~nm}$ (waveband $0.5 \mathrm{~nm}$ ). For the measurement of the absorbance, polystyrene cuvettes (Greiner, Nürtingen, Germany) were used. Oxalate was calculated using the calibrator of the test kit.

An aliquot of $1 \mathrm{ml}$ of the solution of oxalic acid to be measured was bound to an adsorber specific to the test. This oxalate was then set free using $0.2 \mathrm{~mol} / 1 \mathrm{NaOH}$ and further processed in accordance with the test requirements. Each measurement series was accompanied by a blank and a calibrator. The analyses were performed in duplicate. Each sample examined was accompanied by an internal oxalate standard $(4.5 \mathrm{mmol} / \mathrm{l})$ to record the influence of any interfering substances and to correct the results accordingly. The internal standard also served to check the accuracy of the results. In approximately $95 \%$ of all samples the correction factor was between 1.5 and 3 . The recovery varied therefore between 33 and $75 \%$, indicating the presence of substances which had interfered with the determination method. In only a few cases was this factor higher. The interfering substances remain thus far unidentified.

Reproducibility studies yielded an intra-assay coefficient of variation of $2 \%(n=10)$, and an inter-assay coefficient of variation of $5 \%(n=11)$ when a lyophilized urine specimen was examined for oxalate (mean value $0.26 \mathrm{mmol} / \mathrm{l}$ ) with this test system. Using two different lyophilized saliva samples the intra-assay coefficient of

\footnotetext{
1) Enzyme

Oxalate oxidase (EC 1.2.3.4)
}

variation was 1.8 and $2.2 \%(n=10)$, and the inter-assay coefficient of variation 5.4 and $8.6 \%(n=11)$.

\section{Statistics}

In order for the investigations to yield statistically valid results, experimental groups with the same or similar variable constellations were created. The statistical package SAS was used. Since the oxalate concentrations between the different groups differed little from each other, the number of cases in the groups of the human teeth turned out to be so small that no meaningful statistical significance could be shown.

\section{Results}

Whenever possible, results are given as mean \pm standard deviation.

\section{Oxalic acid in saliva}

Saliva samples $(n=167)$, which had been collected from the test subjects in the afternoon, were examined. The saliva from the dentally healthy male subjects $(\mathrm{n}=41$ ) contained $0.1 \pm 0.09 \mathrm{mmol} / \mathrm{l}$, those of the dentally healthy female subjects $(n=40) 0.18 \pm 0.17$ $\mathrm{mmol} / \mathrm{l}$. Table 1 shows the oxalic acid concentration in saliva of these subjects, divided into three age groups. In table 2 the oxalic acid concentration in the saliva of dentally healthy smokers is shown.

Tab. 1 Relationship between age and oxalic acid concentration $(\mathrm{mmol} / \mathrm{l})$ in saliva from dentally healthy test subjects.

\begin{tabular}{lllllll}
\hline Age & $\begin{array}{l}\text { Men } \\
\text { Oxalic acid }\end{array}$ & & & $\begin{array}{l}\text { Women } \\
\text { Oxalic acid }\end{array}$ \\
\cline { 2 - 3 } \cline { 5 - 6 } & {$[\mathrm{mmol} / \mathrm{l}]$} & $(\mathrm{n})$ & & {$[\mathrm{mmol} / \mathrm{l}]$} & $(\mathrm{n})$ \\
\hline $10-25$ & $0.09 \pm 0.07$ & $(12)$ & & $0.17 \pm 0.09$ & $(19)$ \\
range & $0.02-0.26$ & & & $0.09-0.50$ & \\
$26-50$ & $0.12 \pm 0.10$ & $(23)$ & & $0.16 \pm 0.09$ & $(7)$ \\
range & $0.01-0.49$ & & & $0.07-1.10$ & \\
$>50$ & $0.13 \pm 0.09$ & $(6)$ & & $0.13 \pm 0.07$ & $(14)$ \\
range & $0.03-0.24$ & & $0.09-0.27$ & \\
\hline
\end{tabular}

Tab. 2 Oxalic acid concentration in saliva from dentally healthy smokers.

\begin{tabular}{lll}
\hline & $\begin{array}{l}\text { Men } \\
(\mathrm{n}=17)\end{array}$ & $\begin{array}{l}\text { Women } \\
(\mathrm{n}=9)\end{array}$ \\
\hline Age [a] & $16-69$ & $41-66$ \\
& & \\
Oxalic acid concentration, & & $0.21 \pm 0.09$ \\
mean [mmol/1] & $0.20 \pm 0.16$ & $0.09-0.38$ \\
range [mmol/1] & $0.0 \bar{m}-0.78$ & \\
\hline
\end{tabular}


In five male smokers aged from 16 to 53 with carious lesions, the oxalic acid concentration in saliva was 0.09 $\mathrm{mmol} / \mathrm{l}, 0.13 \mathrm{mmol} / 1,0.19 \mathrm{mmol} / \mathrm{l}, 0.23 \mathrm{mmol} / 1$ and 0.04 $\mathrm{mmol} / \mathrm{l}$. In one 24 and one 50 year-old female smoker with carious lesions the oxalic acid concentration in saliva was 0.27 and $0.07 \mathrm{mmol} / \mathrm{l}$, respectively.

In table 3 the oxalic acid concentration in saliva from men and women with carious lesions is shown.

\section{Oxalic acid in tartar}

Tartar sufficient for the determination of oxalic acid could be obtained from 16 patients. In these patients a mean oxalic acid content of $3.3 \pm 1.2 \mathrm{mmol} / \mathrm{kg}$ tartar was found with a concentration varying between 2.8 and $11.8 \mathrm{mmol} / \mathrm{kg}$ tartar. Information regarding the age and sex of the patients was not available.

\section{Oxalic acid in human teeth}

The human molars examined were sorted by dentition. Their oxalic acid content is shown in table 4 . Both healthy and diseased teeth are included.

Table 5 shows the oxalic acid concentrations in defective molars, sorted into age groups.

In a further investigation, the remaining incisors, premolars and molars of test subjects ranging in age from 18 to 67 years were examined. The results are shown in table 6 .

Tab. 3 Oxalic acid content in saliva from male and female subjects with carious lesions.

\begin{tabular}{lll}
\hline & $\begin{array}{l}\text { Men } \\
(\mathrm{n}=17)\end{array}$ & $\begin{array}{l}\text { Women } \\
(\mathrm{n}=8)\end{array}$ \\
\hline Age [a] & $16-74$ & $16-66$ \\
$\begin{array}{l}\text { Oxalic acid conicentration; } \\
\text { mean [mmol/1] } \\
\text { range [mmol/1] }\end{array}$ & $0.21 \pm 0.18$ & $0.20 \pm 0.08$ \\
\hline
\end{tabular}

Tab. 4 Mean oxalic acid content in human molars of both dentitions.

\begin{tabular}{lll}
\hline & $\begin{array}{l}\text { Milk } \\
\text { tẹeth } \\
(\mathrm{n}=12)\end{array}$ & $\begin{array}{l}\text { Permanent } \\
\text { teeth } \\
(\mathrm{n}=60)\end{array}$ \\
\hline Age [a] & $7-11$ & $11-78$ \\
$\begin{array}{l}\text { Oxalic acid concentration, } \\
\text { mean [mmol/kg] } \\
\text { range [mmol/kg] }\end{array}$ & $1.0 \pm 0.30$ & $0.9 \pm 0.60$ \\
\hline
\end{tabular}

Tab. 5 Mean oxalic acid content in defective molars, by age.

\begin{tabular}{llll}
\hline Age range & $10-30[\mathrm{a}]$ & $31-50[\mathrm{a}]$ & $>50[\mathrm{a}]$ \\
\hline Number of cases & 16 & 16 & 8 \\
$\begin{array}{l}\text { Oxalic acid } \\
\text { concentration, }\end{array}$ & & & \\
mean [mmol $/ \mathrm{kg}$ ] & $1.0 \pm 1.8$ & $0.8 \pm 0.60$ & $0.9 \pm 0.60$ \\
range [mmol/kg] & $0.1-3.0$ & $0.2-2.7$ & $0.2-1.0$ \\
\hline
\end{tabular}

Tab. 6 Oxalic acid in human incisors, premolars and molars (including healthy and diseased teeth).

\begin{tabular}{llll}
\hline & Incisors & Premolars & Molars \\
\hline Healthy teeth & $(\mathrm{n}=8)$ & $(\mathrm{n}=9)$ & $(\mathrm{n}=13)$ \\
$\begin{array}{l}\text { Oxalic acid } \\
\text { concentration, }\end{array}$ & & & \\
mean [mmol/kg] & $0.4 \pm 0.01$ & $0.6 \pm 0.02$ & $0.8 \pm 0.03$ \\
range [mmol/kg] & $0.3-0.70$ & $0.2-0.80$ & $0.2-1.60$ \\
Diseased teeth & $(\mathrm{n}=16)$ & $(\mathrm{n}=7)$ & $(\mathrm{n}=34)$ \\
$\begin{array}{l}\text { Oxalic acid } \\
\text { concentration, }\end{array}$ & & & \\
mean [mmol/kg] & $0.8 \pm 0.70$ & $0.7 \pm 0.30$ & $0.9 \pm 0.70$ \\
range [mmol/kg] & $0.1-2.20$ & $0.3-1.00$ & $0.1-2.70$ \\
\hline
\end{tabular}

When all healthy permanent teeth were compared with all diseased permanent teeth without consideration of age, sex or type of tooth, a mean oxalic acid content of $0.9 \pm 0.6 \mathrm{mmol} / \mathrm{kg}$ tooth was found in the $\mathrm{n}=64$ diseased teeth, and in the $n=49$ healthy teeth a mean oxalic acid content of $0.8 \pm 0.4 \mathrm{mmol} / \mathrm{kg}$ tooth.

When these teeth were then sorted by sex, a mean oxalic acid content of $0.9 \pm 0.7 \mathrm{mmol} / \mathrm{kg}$ tooth was found in diseased teeth from women $(n=33)$, and $0.9 \pm 0.6$ $\mathrm{mmol} / \mathrm{kg}$ tooth for men $(\mathrm{n}=31)$. In the healthy teeth of women $(n=28)$, an oxalic acid content of $0.8 \pm 0.3$ $\mathrm{mmol} / \mathrm{kg}$ tooth was found, and in men $(\mathrm{n}=21) 0.7$ $\pm 0.4 \mathrm{mmol} / \mathrm{kg}$.

\section{Oxalic acid in animal teeth}

Table 7 shows the mean oxalic acid concentrations found in animal teeth.

\section{Discussion}

The determination of oxalic acid in urine, plasma and blood as well as in tissues is complicated by the fact that glyoxalate and, in particular, ascorbate can gradually change into oxalate non-enzymatically at $\mathrm{pH}>4$, event at $-20^{\circ} \mathrm{C}(9-11)$. The reason for this phenome- 
Tab. 7 Mean oxalic acid concentration in animal tecth.

\begin{tabular}{lrl}
\hline Species & (n) & $\begin{array}{l}\text { Oxalic acid } \\
\text { [mmol/kg tooth, } \\
\text { dry weight] }\end{array}$ \\
\hline Cow & $(64)$ & $0.8 \pm 0.20$ \\
Pig & $(66)$ & $0.9 \pm 0.20$ \\
Dog & $(7)$ & $1.4 \pm 0.30$ \\
Cat & $(13)$ & $1.7 \pm 0.70$ \\
Rabbit & $(14)$ & $1.3 \pm 0.70$ \\
Fox & $(17)$ & $2.0 \pm 0.70$ \\
Roe Deer & $(31)$ & $1.4 \pm 0.70$ \\
Wild Boar (molars) & $(11)$ & $1.8 \pm 0.70$ \\
Wild Boar (fangs) & $(7)$ & $2.9 \pm 0.40$ \\
\hline
\end{tabular}

non is not clear. For this reason, we processed the acidified samples immediately. To correct the low recoveries indicating unknown interfering substances with the determination method, we used internal standards.

As oxalic acid occurs in plasma at concentrations around $0.01-0.02 \mathrm{mmol} / 1$ (12), the occurence of oxalic acid in saliva is not surprising, even though saliva is not simply a filtrate of plasma. The oxalic acid concentration in saliva is, however, around ten times that in blood. The unanswered question is how the oxalate gets into the saliva. That the oxalic acid is formed from ascorbate would appear unlikely, since the ascorbate level in saliva is very low or not measurable at all (13). At any rate, there is no correlation with the plasma-ascorbate level $(13-16)$. Since there is a correlation between the plasma ascorbate level and leukocyte-ascorbate, the oxalic acid in saliva could be a product of leukocyte metabolism. The leukocytes also contribute to the formation of hydrogen peroxide in the oral cavity by the formation of $\mathrm{H}_{2} \mathrm{O}_{2}$ and glyoxylic acid from glycine by means of an FAD-dependent $D$-aminooxidase (17). Formation by oral cavity bacteria is also conceivable, as several species of Streptomyces and Aspergillus produce oxalic acid $(18,19)$.

It is also conceivable that the oxalic acid measured in saliva is dependent on the food consumed. The oxalate content in the daily diet can fluctuate considerably. Singh et al. (20) determined fluctuations of approx. 0.89 to $22.2 \mathrm{mmol} / \mathrm{day}$ in the diet of the Indian population. For a saliva analysis independent of the circadian rhythm of eating, samples taken from subjects with an empty stomach would be best suited. As organiżational problems arose, samples were taken in the afternoon (before afternoon coffee or tea) as a compromise. Individual differences in salivation rate contributed to the large variation range of the saliva oxalate concentrations.

Omori et al. (21) demonstrated the existence of oxalic acid in saliva using HPLC methods. The oxalic acid concentrations given by these authors were lower than ours. Yamamoto et al. (8) and Omori et al. (21) found oxalic acid in salivary stones and saw a close connection between their formation and oxalic acid.

As our experiments have shown, oxalic acid can also be found in teeth. However, we are at present not yet certain in which dental tissue the oxalic acid is to be found. Oxalic acid can reach the tooth not only through the blood, but through saliva as well. As oxalic acid can be found in bones in concentrations of $0.3-0.4 \mathrm{mmol} / \mathrm{kg}$ dry substance (22), the oxalate content of the teeth should not depend solely on a secretion on the tooth surface in the form of pellicle or plaque formation. Milk teeth contained, on average, more oxalic acid than permanent teeth; however, as a result of the small case groups and the high mean variation, the difference was not significant. In the teeth from women, slightly higher values were measured than in the teeth from men. As men secrete more oxalic acid than women and children (23), assuming the same diet, more oxalate should remain in the organism in women and children. This presumption could apply at least for teeth. The oxalate content may possibly rise from anterior to posterior, as shown by the examination of the incisors, premolars and molars. During the chewing process, the molars stay in contact with the chyme the longest. The higher oxalic acid content in animal teeth could be associated primarily with a different diet. It must also be taken into consideration that the animals examined eat not only by day, but by night as well. Why the fangs of the wild boar show a particularly high oxalic acid content remains an open question.

As oxalic acid in organisms is histologically more prone to be deposited on lesions (24), it is not at all surprising that it is deposited on carious teeth. The oxalic acid concentration in tartar is around one hundred times greater than in saliva, based on the same mass. As oxalic acid comes in contact with calcium-rich tissue, calcium oxalate is formed, which is known for its high degree of insolubility in water. In this manner, the open dentinal canaliculi are provided with an effective "physiological" protective mechanism. Schmidt (25) investigated the su= perficial histological effect of oxalic acid applied to teeth with aid of the relief adhesion method and discovered a sealing effect by the formation of crystals on the enamel surface of teeth. A preceding fluoride treatment provoked a particularly thick deposit of crystals. Thus, nature itself already accomplishes that which is only being tested in dental therapy, namely treatment with preparations containing oxalate to reduce dentin permeability and sensitivity (26). 


\section{Acknowledgement}

The authors wish to express their gratitude to the dentists Drs. $A$. Körber, F. Wissner, P. Ruf, R. Klein, K. Schneider, W. Klein, A. Schorm, $M$. König for supplying the specimens used in this study

\section{References}

1. Schmidt, H. (1982) Biochemie für Stomatologen, p. 421, J. A. Barth, Leipzig.

2. Dunlop, J. C. (1896) The excretion of oxalic acid in urine and its bearing on the pathological condition known as oxaluria. J. Pathol. Bacteriol. 3, 389-429.

3. Zarembski, P. M. \& Hodgkinson, A. (1969) Some factors influencing the urinary excretion of oxalic acid in man. Clin. Chim. Acta 25, 1-10.

4. Sheinkman, E. A. (1940) Characterisation of the products of chemical and biological decomposition of ascorbic acid. III. Effect of ascorbic acid on the excretion of oxalic acid by guinea pigs. Biochem. J. (Ukraine) 16, 397-409.

5. Lamden, M. P. \& Chrystowski, G. A. (1954) Urinary oxalate excretion by man following ascorbic acid ingestion. Proc. Soc. Exp. Biol. Med. 85, 190-192.

6. Gortner, R. A., McCay, C. M., Restarski, J. S. \& Schlack, C. A. (1946) Some effects of dietary oxalate on the teeth of white rats. J. Nutr. $32,121-131$

7. Pashley, D. H., Stewart, F. P. \& Galloway, S. E. (1984) Effects of air-drying in vitro on human dentin permeability. Arch. Oral Biol. 29, 379-383.

8. Yamamoto, H., Sakae, T., Takagi, M., Otake, S. \& Hirai, G. (1983) Weddellite in submandibular gland calculus. J. Dent. Res. 62, 16-19.

9. Kasidas, G. P. \& Rose, G. A. (1986) Measurement of plasma oxalate in healthy subjects and in patients with chronic renal failure using immobilised oxalate oxidase. Clin. Chim. Acta $154,49-58$.

10. Costello, J. \& Landwehr, D. M. (1988) Determination of oxalate concentration in blood. Clin. Chem. 34, 1540-1544.

11. Berckmans, R. J. \& Boer, P. (1988) An inexpensive method for sensitive enzymatic determination of oxalate in urine and plasma. Clin. Chem. 34, 1451-1455.

12. Tietz, N. W. (1986) Textbook of Clinical Chemistry, 3rd edn., p. 1839 , Saunders, Philadelphỉa

13. Bates, J. F., Hughes, R. E. \& Hurley, R. J. (1972) Ascorbic acid status in man: Measurements of salivary, plasma and white blood cell concentration. Arch. Oral Biol. 17, 10171020.

14. Mäkilä, E. \& Kirveskari, P. (1969) A study of ascorbic acid in humanan saliva. Arch. Oral Biol. 14, 1285-1292. and for their valuable technical help and to Mr. and Mrs. Wood for their linguistic assistance.

15. Feller, R. P., Black, H. S. \& Shannon, I. L. (1975) Evidence for absence of ascorbic acid in human saliva. Arch. Oral Biol. $20,563-566$.

16. Leggott, P. J., Robertson, P. B., Rothman, D. L., Murray, P. A. \& Jacob, R. A. (1986) Response of lingual ascorbic acid test and salivary ascorbate levels to changes in ascorbic acid intake. J. Dent. Res. 65, 131-134.

17. Buddecke, E. (1981) Biochemische Grundlagen der Zahnmedizin, p. 102, de Gruyter, Berlin-New York.

18. Rózycki, H. \& Strzelczyk, E. (1986) Organic acids production by Streptomyces spp. isolated from soil, rhizosphere and mycorrhizosphere of pine (Pinus sylvestris L.). Plant and Soil 96, 337-345.

19. Houck, D. R. \& Inamine, E. (1987) Oxalic acid biosynthesis and oxalacetate acetylhydrolase activity in Streptomyces cattleya. Arch. Biochem. Biophys. 259, 58-65.

20. Singh, P. P., Kothari, L. K., Sharma, D. C. \& Saxena, S. N. (1972) Nutritional value of foods in relation to their oxalic acid content. Am. J. Clin. Nutr. 25, 1147-1152.

21. Omori, H., Sakakibara, T. \& Nakashizuka, T. (1986) Oxalic acid levels in saliva, plaque, soft calculus and calculus. J. Dent. Res. 65, 837 (abstract 1007).

22. Schäfer, H.-J. (1989) Oxalsäurekonzentration im menschlichen Knochen, Doctoral Dissertation, University of Tübingen.

23. Hodgkinson, A. \& Zarembski, P. M. (1968) Oxalic acid metabolism in man: A review. Calcif. Tissue Res. 2, 115-132.

24. Gatter, R. A. \& McCarty, D. J. (1967) Pathological tissue calcifications in man. Arch. Pathol. 84, 346-353.

25. Schmidt, H. F. M. (1971) Oberflächenhistologische Untersuchungen über Veränderungen der Schmelzoberfläche durch Oxalsäure und oxalsäurehaltige Nahrungsmittel. Stoma 24, 26-33.

26. Mongiorgi, R., Prati, C., Toschi, E. \& Riva di Sanseverino, L. (1991) Oxalate desensitising treatment of dentinal surface. Boll. Soc. Ital. Biol. Sper. LXVII, 403-407.

Priv.-Doz. Dr. med. Richard Wahl

Medizinische Klinik und Poliklinik, Abt. IV

Eberhard-Karls-Universität

D-72076 Tübingen

Germany 
